\title{
Estella Ciobanu*
}

\section{“THE PLAY'S THE THING": RE-IMAGINING SHAKESPEARE'S THE TEMPEST IN FORBIDDEN PLANET, PROSPERO'S BOOKS AND HAG-SEED}

\begin{abstract}
This paper examines a number of contemporary adaptations of The Tempest - Fred McLeod Wilcox's Forbidden Planet (1956), Peter Greenaway's Prospero's Books (1991) and Margaret Atwood's Hag-Seed (2016) - which indicate new avenues for exploring the phenomenon of past-and-present re-bonding through re-telling. If adaptation theory suggests, at its best, that an adaptation may encourage the public to read the adapted text, if unfamiliar, as Linda Hutcheon argues, these particular adaptations of Shakespeare's play, I contend, take a step forward. Not only do they spur their readers/spectators on to (re)read The Tempest, but they elicit (re)considering the relationships amongst (certain of) Shakespeare's plays. It is what happened to this author too whilst reading Hag-Seed, even before reaching the page where Atwood's protagonist Felix qua Prospero actor and figure - contemplates the opportunity offered by mounting The Tempest to unmask his usurpers. "The play's the thing", Felix thinks in Hamletian terms, allowing the readers familiar with Hamlet to complete mentally "wherein I'll catch the conscience of the king". More than being Shakespeare's swan song, as typically regarded, The Tempest thus becomes the metatheatrical light on Hamlet's own metatheatricality - also courtesy of the former's adaptations.

Keywords: The Tempest (Shakespeare); Forbidden Planet (directed by Fred McLeod Wilcox); Prospero's Books (written and directed by Peter Greenaway); Hag-Seed (Margaret Atwood); adaptation theory.
\end{abstract}

1956: Metro-Goldwyn-Mayer releases Forbidden Planet, directed by Fred McLeod Wilcox. It is doubtful whether many 1950s spectators realised that the plot rewrites Shakespeare's The Tempest in science-fiction key, if tinted with Freudian hints. 1991: Prospero's Books, written and directed by Peter Greenaway, is released. In this avant-garde adaptation of The Tempest, Prospero gives voice to

* Ovidius University of Constanţa; Romania. 
all the other characters - who become "his creation" - "up to the crucial turning point" (Klein n.p.). Prospero is thus "the author, the producer and main character of the play which unfolds before our eyes" (Klein n.p.) and which will fill the 'empty place' of Shakespeare's First Folio (1623) that Prospero has brought along on the island. 2016: Margaret Atwood publishes Hag-Seed, ${ }^{1}$ commissioned as part of the Hogarth Shakespeare series. Atwood's novel centres on the mounting of The Tempest in a prison, if aimed at revenge, which renders Shakespeare's text "a play within a play within a novel" (Groskop n.p.) ${ }^{2}$ - not such a far cry from Shakespeare's metatheatrical play. How do such "palimpsestic" works, or works in the "second degree" (both Genette's terms), ${ }^{3}$ explore/exploit The Tempest and what do they mine out of its depths? This paper contends that these works do not only spur their readers/spectators on to (re-)read The Tempest, as Linda Hutcheon argues about adaptation, but also elicit (re)considering the relationships amongst (certain of) Shakespeare's plays.

\section{Adaptation: the basics}

All the above cases are more - or less - avowed adaptations - hence "a form of repetition without replication" (Hutcheon, Theory of Adaptation ${ }^{4}$ xvi, 7), or "repetition with variation" (Hutcheon, TA 4) - of Shakespeare's play. Adaptation easily yields to being maligned as "a tampering, a deformation, a desecration, an infidelity, a betrayal, a perversion" (Hutcheon, "Art of Adaptation" 5 109; see also

\footnotetext{
${ }^{1}$ Atwood's title quotes one of the pejorative terms used by Prospero to address his slave Caliban (Tempest 1.2.366) right when the former dispatches the latter to fetch firewood, after a protracted argument regarding Prospero's usurpation of Caliban's inheritance of the island. "Hag-seed" features amongst the only swear-words - all quotations from Shakespeare's play - permitted by Felix as instructor-cum-stage director to be used by his inmates-cum-student-actors during their rehearsals of The Tempest; it also provides the title of chapters 28 (in Part III) and 45 (as "Team HagSeed" in Part V).

${ }^{2}$ Whilst explaining to his 'actors' the roles of the island in The Tempest, at the beginning of their work on it, Felix muses: "the island is a theatre. Prospero is a director. He's putting on a play, within which there's another play" (Atwood 116).

3 Genette dubs adaptation hypertextuality through transformation. Hypertextuality names "any relationship uniting a text $\mathrm{B}$ (... the hypertext) to an earlier text $\mathrm{A}(.$. the hypotext), upon which it is grafted in a manner that is not of commentary" (Genette 5); in more general terms, text B is "a text derived from another preexisting text" (5). When text B does not "speak [...] of text A at all" or cite it, but cannot "exist, as such, without A", this is an instance of transformation (5).

${ }^{4}$ Henceforth abbreviated TA.

${ }^{5}$ Henceforth abbreviated "AA".
} 
Hutcheon, TA 2-3) decried, in its filmic/televisual mode, as "a wilfully inferior form of cognition" (Newman, qtd. in Hutcheon, TA 3).

Yet, such "critical abuse" (Hutcheon, TA xii) can also be challenged on manifold counts. Not only is adaptation ubiquitous nowadays in all media (TA 2), but as a practice of "sharing stories", adaptation boasts a venerable history (Hutcheon, "AA" 110, original emphasis). Certainly, both aspects hardly provide or support a robust argument in favour of adaptation. However, there is more to adaptation than its detractors concede, and, pace Hutcheon, it indicates more than a postmodern "de-hierarchizing impulse" (TA xii).

For Hutcheon, adaptation is rather "a fundamental operation of the storytelling imagination" ("AA" 111) whose novelty concerns "what one does with the other text" (TA 20, original emphasis). Simply stated, adaptation has been one highly popular and enduring "creative way [...] of deriving art from art" ("AA" 109). Its denigration - the unavoidable outcome of "our post-romantic valuing of the originary" ("AA" 110) and of "the originating creative genius" (TA 3-4) - may partly owe to a certain dimension of its "human, experiential context" (TA xii) worth investigating in terms of "the politics of intertextuality" (TA xii, original emphasis). Both the adapted work and the adaptation have to do with the cultural capital ("AA" 109) associated with the assumed hierarchy of media and genres (TA 3,91-2), or else why would an opera or a ballet adaptation of Shakespeare never be denigrated, unlike a film adaptation $(T A 3,85)$ ?

\section{"The play's the thing wherein I'll catch the conscience of the king"}

"The play's the thing" (Hamlet 2.2.557-558), Hamlet soliloquises, embittered that his duty to revenge his father is impeded by his philosophically argued procrastination. The conclusion follows the dialogue in which he has requested the Players to perform his enhanced version of "The Murder of Gonzago" before King Claudius and his court. "The play's the thing" may have felt too - albeit presumably unconsciously in most cases and prompted by different circumstances - the creators of various adaptations of The Tempest. Tellingly, in Hag-Seed the protagonist's free indirect thought - "The play's the thing" fragmentary sentence - warns the readers of his implicitly Hamletian ploy to catch the conscience of his usurpers by "help[ing] the actors help him execute it" (Atwood 133).

\section{Forbidden Planet}


University of Bucharest Review $\approx$ Vol. X/2020, no. 2 (new series)

Re-writing, Re-imagining the Past (II)

What/whose conscience is there to catch and in what kind of play in Forbidden Planet (1956)? Set in 2200, this sci-fi cult film contemporaneous with the beginnings of space exploration resonates with the 1950s' fears of misuse of technology (already 'predicted' by Huxley in his 1932 Brave New World), especially of nuclear power, and Cold-War associated nightmares of being invaded (Zabus 192-3; cf. Bucher 142-3). Notwithstanding, the ideational armature of Forbidden Planet ${ }^{6}$ is modelled on The Tempest (Bucher n. 2), ${ }^{7}$ if "crossed with Frankenstein and a good mystery story" centred on the enigma of the Krell (Tashiro n.p.) and grafted with loose Freudian ideas modelled on Sophocles's Oedipus Rex (Bucher 123-4) and R. L. Stevenson's Dr Jekyll and Mr Hide (Dirks n.p.). The film's complex intertextual underpinnings spur the educated spectator to reconsider The Tempest as "an ancestor to modern science fiction" - "a utopia toying with power, 'aliens', and the island motif" (Zabus 182). Furthermore, the film's "double focus", in J. P. Telotte's terms (qtd. in Zabus 182), i.e., its unveiling of dystopia within utopia, can shed new light, I suggest, on The Tempest's own interplay of utopia and dystopia.

Forbidden Planet fathoms, in loose Freudian terms, the deep-seated will to power run amok in a Faustus figure, Dr Edward Morbius (Walter Pidgeon), a philologist turned scientist, self-exiled on an uninhabited planet and having meanwhile begotten a daughter, Altaira/Alta (Anne Francis). Father and daughter live peacefully in the paradisiacal desert world of Altair-IV, whose early, highly advanced civilisation, the Krell, has been extinct for two millennia. In lands United Planets space cruiser C-57D, tasked to determine what happened twenty years before with the Bellerophon spaceship and the human colony it planted on Altair-IV. After a brief erotic interlude initiated by Lieutenant Jerry Farman (Jack Kelly), Altaira falls in love with Commander John Adams (Leslie Nielsen), which enrages her father and unleashes his jealousy. On the face of it, the Morbius-Altaira-Adams triangle neatly replicates Shakespeare's ProsperoMiranda-Ferdinand, whilst Shakespeare's island is projected from the ocean into outer space.

\footnotetext{
${ }^{6}$ The film credits Irving Block and Allen Adler's story, actually the first script ("Fatal Planet"), alongside Cyril Hume's script proper; the latter was novelized (as Forbidden Planet, 1956) by W. J. Stuart (Bucher 125).

${ }^{7}$ Forbidden Planet "has read the space island, at the very outset of space conquest in Fifties America, as a metaphor for the early American colony." (Zabus 181)
} 
Yet the film is more than a middlebrow adaptation of The Tempest for sci-fi lovers. The last words of the crew's physician and Gonzalo-figure, Lieutenant "Doc" Ostrow (Warren Stevens), enable Adams to understand the techno-

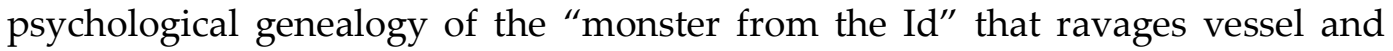
crew, and will later also ravage Morbius's house built atop the Krell's underground laboratory. The invisible feral giant creature that kills several crew members is but a projection of Morbius's anger released from the Id through the power of the Krell's "big machine", the artificial intellect expander. (Morbius has used the machine to augment his cognitive capacity, yet thereby the machine has 'accessed' and materialised what seethes in his unconscious. ${ }^{8}$ ) Reading Forbidden Planet's Freudian psychologising with R. L. Stevenson's Dr Jekyll and Mr Hide renders Shakespeare's Caliban "this thing of darkness" whom Morbius/Prospero has to "[a]cknowledge mine" (Tempest 5.1.278-279) literally, as his underside (Zabus 177, 186; Sheppard, qtd. in Bucher n. 39). Thus, Forbidden Planet, I argue, re-writes Hamlet's "O God, I could be bounded in a nutshell, and count myself a king of infinite space, were it not that I have bad dreams" (Hamlet 2.2.243-4) as Morbius's 'bad dreams' externalised in monster form by the Krell machine and via Goya's imaginary of the outcome of the sleep of reason.

Nor is Forbidden Planet's Ariel uncomplicated (pace Dirks n.p.). On the face of it, Ariel is Robby, the robot created by Dr Morbius to obey, serve and protect, yet never harm, humans. Nonetheless, insofar as Morbius drew on the Krell's ideas to design Robby (00:53:46-00:53:53; see also 00:53:46-00:53:53), this latterday Ariel belongs with the technological legacy of the Krell which has also generated Morbius's destructive monster. Thus, Robby/Ariel, I suggest, becomes the other face of Morbius/Prospero/Caliban. Furthermore, Robby as tireless servant indispensable to Morbius takes after Shakespeare's Caliban (Zabus 184), about whom Prospero says: "We cannot miss him. He . . . . . . serves in offices / That profit us" (Tempest 1.2.312-314). Forbidden Planet further ambiguates the Robby/Ariel partial overlap by having the robot manufacture the spirits which

\footnotetext{
8 These monsters became the nemesis of the Krell. Through the Id-Monster as the "demon within" (Zabus 187) released by Morbius during his sleep - the sleep which "Prospero enforces on his daughter and his victims alike" (187) - and owing its original externalisation to the technology in the underground Krell laboratory, a link is forged between "forbidden knowledge, the power of unreason, and Morbius's secret studies, which he carries out in a noetic subworld" (187). Thus, "the journey to an outer planet is also a journey into the interior" which proves that "outer space can contain 'inner space'." (187)
} 
will inebriate the space cruiser's cook (Earl Holliman) and presumably Robby, his drinking mate, too - a tongue-in-cheek reversal of Shakespeare's Stephano's designs on Caliban and of his and Trinculo's drunkenness (and later Caliban's). Conversely, the "monster from the Id" - the film's Caliban - is as protean in form and as invisible as Shakespeare's Ariel is (Zabus 185-6).

Whose is the conscience - or rather whose are the unconscious, atavistic drives - caught in the dangerous technological play, in Forbidden Planet? Morbius's? The Krell's millennia before? Humanity's outside the film in (and before) the mid-1950s? What is, moreover, the forbidden planet of the title? Is it simply Altair-IV, the planet haunted by technologically visualised "monsters from the Id"? Is it the technological utopia (here symbolised by the Krell civilisation) shown to be dystopic in its effects at least ever since the 1945 detonation of the nuclear bomb? Is it forbidden knowledge - the knowledge of good and evil which Yahweh forbids to Adam for mysterious reasons (Gen 2.17, $N R S V$ ) and which later the church fathers connected with 'guilty' sexuality? ${ }^{9}$ Is it the far-reaching rational mind, shown - by Goya, Freud and others - to be no Cartesian blessing, but a heterotopia of desires, ideas and ideals, an alien(ating) construct more than a biological given? Is it the will to power, whether power/knowledge or political-military colonial power - the power which Morbius wants to be his alone and which he regards as dangerous if shared liberally with the others (cf. Gen 3.22)? Substitute 'magic' for 'hi-tech' and Prospero for Morbius, and the same questions apply to Shakespeare's The Tempest too.

\section{Prospero's Books}

Prospero's Books (1991) has been praised for its technological and visual input (Hutcheon, TA 83). A "multimedia composition", the film "explor[es] the potentialities of new multimedia performative spaces" to "recast $[. .$.$] the play's$ exceptional weaving of the multiple codes of Elizabethan drama, including theatre, narration, music, dance and masque" (Squeo 219). It has, however, also been faulted for its "absolutely conventional" "underlying post-Romantic interpretation" (Klein n.p.), since Greenaway regards The Tempest as

\footnotetext{
${ }^{9}$ Accordingly, the Yahweh-figure-cum-Death, Morbius, uses Alta as a bait to lure John Adams - as Adamic figure - and deal him a deadly blow should Adams vie with Morbius for knowledge, hence for power. Thus, the film's implicit re-writing of the biblical story, I contend, suggests Yahweh's non-innocence (see Gen 2.15-17; Gen 3.1-5, 22-4).
} 
"Shakespeare's 'Legacy to Posterity' in which the author identifies himself with the main character" (Klein n.p.). Already the title frames the film as one of (and by) the book; Greenaway admits: "[t]he project deliberately emphasises and celebrates the text as text, as the master material on which all the magic, illusion and deception of the play is based" (qtd. in Squeo 219). Books ${ }^{10}$ provide the hard core of the film/play unfolding before the spectators' eyes, as cued by Caliban (Tempest 3.2.84-93). Thus, Shakespeare's play's action proper becomes, arguably, secondary to - by being framed by - the books of diverse knowledge.

Greenaway's film starts with Prospero (John Gielgud) writing - and soon voicing-over - his explanation to Miranda (not shown at this point) regarding his beloved books furtively stashed into the boat by Gonzalo (not mentioned here). Prior to that, though, the intertitles suggest that what we are to see is merely a figment of Prospero's imagination:

One evening, Prospero imagines creating a storm powerful enough to bring his old enemies to his island. He begins to write a play about his tempest, speaking aloud the lines of each of his characters. It is the story of Prospero's past, and his revenge... (Prospero's Books, 00:00:23-00:00:39)

As will be explicitly shown much later, Greenaway's Prospero writes The Tempest - the play missing from the first folio of Shakespeare's plays, which Prospero has brought with him on the island. Greenaway creates not a mise en abyme, but rather a complex metatheatrical and metadramatic mirroring of texts, auctorial figures and theatrical impersonation. Yet, Prospero's Books strikes me as a film-play not so much about Prospero qua Shakespeare's persona as about Prospero qua Greenaway's persona. Not a swan song play (or film) is this adaptation about - as the adapted play is envisaged - but rather a remediation (Bolter and Grusin 5-15) of adaptation and metatheatre which lays their strings bare. Greenaway yokes such novel take, however, to the rather conservative approach to books as the repository of knowledge, which reflects the 'bourgeois' hierarchy of genres and media. Notwithstanding, bookish authority rests here not with literature, but with the arts and sciences, which makes Greenaway's a tribute not so much to Shakespeare as to books (cf. Hutcheon, TA 8). In Prospero 10 The film's books, "inspired by those of Athanasius Kircher" (Hutcheon, TA 83), include, in the
Book of Water, "extracts from Leonardo da Vinci's drawings on the motion of fluids" (Squeo 229). 
Greenaway dramatises, I suggest, no less than a God-figure writing The Tempest as the story of his (bookish) exploits, his not always faithful followers and his manifold revenge on his trespassers - a Shakespeare-remediated Bible, not just a Genesis 2-3 remediation, as in Forbidden Planet.

\section{Hag-Seed}

Atwood's Hag-Seed is at least every bit as metatheatrical/metafictional as its predecessors reviewed above. As the former artistic director of a Canadian theatre festival and an actor and stage director himself, Felix Phillips is a theatre professional; nonetheless, the ones with and for whom he produces The Tempest are, with minor exceptions, no such professionals. Atwood's protagonist - under the (for readers) telling name of F. Duke - is now an instructor for the inmates of the Fletcher County Correctional, whom he teaches literacy through acting Shakespeare. ${ }^{11}$ His Tempest actors and part of the audience are prison inmates, as in the previous three years at Fletcher; the remainder of the audience are prison personnel and a handful of cabinet dignitaries. ${ }^{12}$ The very purpose of the production is revenge: Felix wishes to avenge his removal from the theatre through petty plotting (Atwood 41). The play would accomplish yet another goal: to resurrect his dead daughter, Miranda. Or so Felix thought originally, when he intended to produce the play for the Makeshiweg festival. (Atwood 167) Through the belated production of The Tempest - after twelve years (as in Shakespeare) since his self-exile - Felix believes he can "release [...] [his Miranda] from her glass coffin" (Atwood 41), as the prince releases Snow White (cf. Atwood 39) from hers. Miranda "must be given a life" (41), Felix adamantly believes. The play once produced - and revenge successfully carried out - Felix realises, however, that "he's been wrong about this Tempest, wrong for twelve years. The endgame of his obsession wasn't to bring Miranda back to life. The endgame was something quite different" (Atwood 283). The novel ends with

\footnotetext{
${ }^{11}$ Atwood (292) acknowledges being inspired by actual cases; on staging Shakespeare in prisons, see Albanese (120-44) and Cavecchi.

12 Of the latter, Tony Price, Heritage Minister, is Felix's former assistant at the festival and his usurper. Tony's aide, then Heritage Minister, now Justice Minister, is Sal O'Nally, whose son, Fred, a graduate in theatre studies, wishes to start directing and will be later helped by Felix, once restored as artistic director. Veteran Affairs Minister, Sebert Stanley, is Sal's political rival and a Sebastian to Tony's Antonio and Sal's Alonso. Lonnie Gordon, former chair of the Festival Board, now the chair of Gordon Strategy, was the only sympathetic, if ineffectual, person at the time of Felix's removal - a Gonzalo figure.
} 
Felix quoting Prospero on releasing Ariel: "To the elements be free" (Atwood 283). ${ }^{13}$ Unbeknownst to Felix at the time, the production becomes his farewell to the memory of his daughter - her release and thereby also his from the prison of memory and mourning, from the haunting past. In Prospero's words, which end Shakespeare's play, "As you [the audience] from crimes would pardoned be, / Let your indulgence set me free" (Tempest, Epilogue 19-20). ${ }^{14}$

It has rightly been noticed that Atwood virtually conflates Shakespeare's Miranda and Ariel, both "airy, ghostly spirit[s], invisible and inaudible to anyone but Felix", but especially catalysts for the protagonist's post-revenge change of heart (Mavensinaguinan n.p.). In Hag-Seed, such change entails acknowledging that the sole driving force behind the production was revenge. Yet, the 'spirits' that enable both production and revenge proper - Atwood's re-vision of Ariel and his legions of elves in the service of Prospero - are inmates. Their current condition (serving sentence) and past misdeeds (the felony conducive to being jailed) render the actors/'spirits' a complex collective Caliban (Mavensinaguinan n.p.) sui generis. This is yet another significant conflation at work in Atwood, which may puzzle as much as the conflations operated by Forbidden Planet do.

With Hag-Seed, we can realise even more compellingly than before the close imbrications not only of power and the theatre, but also, I argue, of Shakespeare's plays. Hamlet's "the play's the thing" provides the metatheatrical connection between political misdemeanour and exposure (as the evidence needed for revenge). His play-within-the play - enacted by the itinerant Players visiting Elsinore - foreshadows the sorcery by which Prospero - aided by Ariel and his elves - mounts a tempest ${ }^{15}$ to make the guilty nobles confess their crimes and repent, then restore the usurped duke to his position of power. The "betrayal" (Atwood 23) and "treacheries" (55) for which Felix blames, retrospectively, Tony and Sal, are those by which both Prospero and King Hamlet lost their power.

Nonetheless, the various conflations of Shakespeare's Tempest characters apparent in Hag-Seed (as well as in Forbidden Planet) indicate yet another avenue

\footnotetext{
13 "Then to the elements / Be free, and fare thou well!" (Tempest 5.1.320-1). But for the invitation to his guests - "Please you draw near" (5.1.321) - these would be Prospero's final words in the play before the Epilogue.

${ }^{14}$ Can le plaisir $d u$ texte indeed save the protagonist from the prison of Shakespeare's text? By that token, however, any character would be always already imprisoned in the text that features them unless and until released through interpretation (largo sensu).

15 The more directly theatrical enactment of the three goddesses' masque is marginal to my argument.
} 
worth pursuing. Shakespeare's final play makes its protagonist a complex character and hardly the unimpeachably 'good guy'. Rather, like Titus Andronicus, himself revenge-driven and a savage no less than the prisoner Goths are, Prospero is sometimes indistinguishable from the savage Caliban and his sorceress-mother, Sycorax. Atwood wastes no opportunity to draw parallels between these characters, if by the metafictional conceit of having the inmate actors devise the afterlives of Shakespeare's characters. In their post-performance assignment, Team Hag-Seed (viz., the Caliban team) proposes that Prospero is Caliban's actual father (Atwood 265-6); "this thing of darkness I / Acknowledge mine" (Tempest 5.1.278-9) yields to literal reading - and misprision, given Shakespeare's context of identifying servant connections. Their proposition, however, concerns the many similarities between the two characters. Prospero "sees that the bad in Caliban is pretty much the same as the bad in him, Prospero": anger, name-calling and revenge are shared 'virtues', according to Team Hag-Seed (Atwood 267). In short, the team concludes, "Caliban is like his [Prospero's] bad other self" (267, emphasis added). Or is it merely a measure of the distorting lens through which we traditionally regard the characters? Earlier in the report, two outstanding remarks suggest the socio-political and imagological stakes of this alter ego relationship. Leggs, the Caliban actor, wonders: "Why's he [Caliban] to suffer so much for being what he is? It's like he's . . . black or Native or something" (Atwood 265). Two paragraphs later, Leggs resumes teasing out the double standard applied to the Tempest characters along racial and/or gender lines:

His [Caliban's] mom is a sorceress, right? Sycorax. She's wicked! Prospero is a sorcerer. They do a lot of the exact same kind of things - charms, spells, changing the weather - including putting the twist on Ariel, except that Prospero does those things better, and we're supposed to think it's okay for him but evil for her. (Atwood 266, emphasis added)

What Leggs and his team fail to mention in this connection is that we encounter Sycorax only through what is reported about her by her detractor, Prospero, who never met her, in dialogue with the still enslaved Ariel ${ }^{16}$ (Tempest

16 "Thou my slave" (Tempest 1.2.271), Prospero addresses Ariel; the same words, "my slave" (1.2.308), are repeatedly used for Caliban. 
1.2.258-285), whom the former presses to recall his bondage under Sycorax. ${ }^{17}$ Sycorax and Caliban yield to monsterisation ${ }^{18}$ by dent of having been the earliest known inhabitants of the island, now pushed aside by the newcomer, rather than through their demonstrable onstage deeds. ${ }^{19}$

Felix as Prospero (yet hardly distinguishable from Caliban at times) covertly overlaps with Ariel too. If as Prospero Felix re-lives his former self as a director, actor and producer, as Ariel he introduces his new self as an invisible trickster who conjures illusions and makes theatre driven by his will to revenge (Atwood 107). Felix's recluse "rustic dwelling" (38) - variously called his "shack" $(31,107)$, "shanty" (33-4), "hovel" (107) or "cave" (106) - provides a valuable clue in this respect. His modest dwelling confines Felix to a drab place comparable both to Prospero's island "cave" (Atwood 113), "cell" (Tempest 1.2.20, 1.2.39, 1.2.348, 4.1.161, 5.1.84, 5.1.166, 5.1.294, 5.1.304; 5.1.171s.d.), or den (Tempest 10, n. $20),{ }^{20}$ and to Caliban's "rocky cell" (Atwood 118), the "hole in the rocks" (Atwood 125), or "hard rock" (Tempest 1.2.344), to which Prospero has confined Caliban. ${ }^{21}$ This cave or cave-like space of confinement, in Shakespeare as in Atwood, recalls, I argue, the cave of illusions mistaken for reality in Plato's famous myth. Illusion or reality is it that Felix, Prospero, Caliban and Ariel share so much in common? To "restore his name" and generally to "vindicate" himself (Atwood 111), Felix resorts to "tricks" (109). As he explains - metatheatrically to his actors, to work out his revenge their performance needs "creating an illusion through doubles", which is "one of the oldest theatrical gimmicks" (108). Felix refers here denotatively to his dual rendition of The Tempest: the inmates'

\footnotetext{
17 There is an intimation - when Prospero chides Ariel - that such memories as Ariel's are 'cultivated' by his master: "I must / Once in a month recount what thou hast been, / Which thou forget'st" (Tempest 1.2.262-4).

${ }_{18}$ According to Cohen (34), in colonial contexts, the conqueror misrepresents the aboriginal group as primitive, subhuman and/or monstrous and dangerous, to justify its subduing and 'civilising'.

${ }^{19}$ According to Prospero's 'reported speech' of Ariel's account ("As thou report'st thyself", Tempest 1.2.272), Sycorax imprisoned the sprite in a pine tree for his refusal to do her commissions (1.2.2501, 1.2.271-80). Conversely, accused by Prospero of having attempted to "violate / The honor" of Miranda (1.2.348-349), Caliban confirms having been prevented from "peopl[ing] . . / This isle with Calibans" (1.2.351-2).

20 "Prospero's cell, too, is apparently a rock cave" (Tempest 32, n. 350). Ariel $(4.1 .182,5.1 .10)$ and Caliban $(4.1 .195,4.1 .215)$ also name it "cell".

21 Prospero [to Caliban]: Therefore wast thou

Deservedly confined into this rock, who hadst

Deserved more than a prison. (Tempest 1.2.361-3)
} 
videoed enactment played back to the prison audience and the 'happening' experienced elsewhere in the prison by the political dignitaries (Atwood 107-8), whereby they willy-nilly re-enact the scenes of exposure and apparent loss in The Tempest. The prison/cave qua isolated island becomes a confining structure for more than the exile; so does the play, in its dual performance. Both types of confinement (in the prison/cave or on the island and in the play, respectively) seek to raise the mirror up to nature - to the characters' inner selves, as Felix explains to his students whilst introducing The Tempest to them (Atwood 115). ${ }^{22}$ A mirror like the wall of Plato's cave - on a prison-island?

\section{Conclusion}

Resonating with postmodernism's critique of representation, "postmodern Tempest-rewritings have endeavoured to wrest Prospero" (Zabus 177) from the role of "privileged Western White Male Global Oppressor", in Daniel T. O'Hara's terms (qtd. in Zabus 177), and point rather to "the interchangeability of Prospero and Caliban" (Zabus 177). The "general cultural critique of authority and the crisis in legitimation inherent in postmodernism" have unpacked the traditional view of Prospero's "monolithicity" (Zabus 177): through introspection, a now fragile Prospero "acknowledges 'this thing of darkness' . . . as 'his', e.g., his own Id (as in Forbidden Planet) or his homosexuality (as in Harry Mulisch's novel [Last Call (1985)] or Philip Osment's play [This Island's Mine (1988)])" (Zabus 177; see also 178-9).

Hamlet remarks: "Denmark's a prison", to which Rosencrantz retorts: "Then is the world one" (Hamlet 2.2.234-5); The Tempest seems to hark back to that exchange. This would explain why Forbidden Planet makes sense as a re-writing of The Tempest (in sci-fi mode) set on a desert planet in outer space, or why Atwood re-writes The Tempest as its staging literally in a prison-house whose inmates must identify the play's series of nesting prisons, or rather prison-chain.

What is noteworthy about contemporary adaptations and postmodern retellings of The Tempest is their capacity to set readers/spectators in intellectual motion and encourage them to re-read Shakespeare's play anew. This is what has happened to me whilst re-reading Atwood's Hag-Seed, when I started reconsidering the relationships amongst Shakespeare's plays even before 22 "Maybe the island really is magic... Maybe it's a kind of mirror: each one sees in it a reflection of
his inner self. Maybe it brings out who you really are" (Atwood 115). 
reaching the page (133) where Atwood's Felix/Prospero/Hamlet contemplates the opportunity offered by mounting The Tempest to unmask his usurpers. The play's the thing wherein I'll catch the conscience of the reader/spectator, such re-tellings seem to suggest.

\section{Works Cited}

Albanese, Denise. Extramural Shakespeare. Reproducing Shakespeare. Palgrave Macmillan, 2010. Print.

Atwood, Margaret. Hag-Seed: The Tempest Retold. Vintage, 2017 (originally published by Hogarth, 2016). Print.

Bolter, Jay David, and Richard Grusin. Remediation: Understanding the New Media. MIT, 1999. Print.

Bucher, Gregory S. "A Complex Oedipus: The Tragedy of Edward Morbius". Classical Traditions in Science Fiction. Ed. Brett M. Rogers and Benjamin Eldon Stevens. Oxford UP, 2015. 123-44. Print.

Cavecchi, Mariacristina. "The Bard Does Not Want to Die (Behind Bars): Rewriting Shakespeare within Volterra Maximum-Security Prison". Rewriting Shakespeare's Plays for and by the Contemporary Stage. Ed. Michael Dobson and Estelle Rivier-Arnaud. Cambridge Scholars Publishing, 2017: 119-34. Print.

Cohen, Jerome Jeffrey. Of Giants: Sex, Monsters, and the Middle Ages. U of Minnesota P, 1999. Print.

Dirks, Tim. "Forbidden Planet (1956)". Filmsite Movie Review. N.d. Web. 29 Jan. 2020. <https://www.filmsite.org/forbiddenplanet.html>.

Forbidden Planet. Dir. Fred McLeod Wilcox. By Cyril Hume, based on a story by Irving Block and Allen Adler. Prod. Nicholas Nayfack. Perf. Walter Pidgeon, Anne Francis, and Leslie Nielsen. Metro-Goldwyn-Mayer, 1956. DVD.

Genette, Gérard. Palimpsests: Literature in the Second Degree. Trans. Channa Newman and Claude Doubinsky. U of Nebraska P, 1997. Print.

Groskop, Viv. "Hag-Seed Review: Margaret Atwood Turns The Tempest into a Perfect Storm". The Guardian, 16 Oct. 2016. Web. 31 Jan. 2020.

$<$ https://www.theguardian.com/books/2016/oct/16/hag-seed-review-margaretatwood-tempest-hogarth-shakespeare>

Hutcheon, Linda. "On the Art of Adaptation". Daedalus 133.2 (2004): 108-11. 
Print.

- A Theory of Adaptation. Routledge, 2006. Print.

Klein, Herbert. "'The far side of the mirror': Peter Greenaway's Prospero's Books". EESE 12 (1996): no pagination. Web. 31 Jan. 2020.

$<$ http://webdoc.sub.gwdg.de/edoc/ia/eese/artic96/klein/12_96.html>

Mavensinaguinan [sic]. "Tempest of the Mind". The Microcosms Within:

Ruminations on Imperial Ruinations. Blog at WordPress.com. Published 20

Feb. 2018. Web. 31 Jan. 2020.

$<$ https://solivagantruminations.word press.com/2018/02/20/tempest-of-the-mind/> The New Oxford Annotated Bible: New Revised Standard Version with Apocrypha (NRSV). Ed. Michael D. Coogan. Fully revised 4th ed. Oxford UP, 2010. Print.

Prospero's Books: An Adaptation of The Tempest by William Shakespeare. Dir. Peter Greenaway. By Peter Greenaway. Prod. Kees Kasander and Philippe Carcassonne. Perf. John Gielgud, Michael Clark, Isabelle Pasco, and Michel Blanc. Allarts, Elsevier-Vendex, Cinéa/Caméra One, Penta, 1991. DVD.

Shakespeare, William. Hamlet, Prince of Denmark. Ed. Philip Edwards. Updated ed. Cambridge UP, 2003. Print.

—. The Tempest. Ed. Burton Raffel. Yale UP, 2006. Print.

Squeo, Alessandra. "Shakespeare's Hypertextual Performances: Remediating The Tempest in Prospero's Books". Revisiting The Tempest: The Capacity to Signify. Ed. Silvia Bigliazzi and Lisanna Calvi. Palgrave Macmillan, 2014: 218-35. Print.

Tashiro, Charles. "Forbidden Planet". Criterion Collection. 3 Apr. 1989. Web. 12 Dec. 2019.

$<$ https://www.criterion.com/current/posts/888-forbidden-planet>

Zabus, Chantal. Tempests after Shakespeare. Palgrave Macmillan, 2002. Print. 